\title{
ITPKB Gene
}

National Cancer Institute

\section{Source}

National Cancer Institute. ITPKB Gene. NCI Thesaurus. Code C148580.

This gene plays a role in the phosphorylation of inositol trisphosphate (IP3). 